\title{
KOULUTUSYHTEISKUNNASTA OPPIMISEN YHTEISKUNTAAN
}

\author{
Aikuisten oppimista on tuettava ratkaisuin, jotka ottavat \\ huomioon heidän lähtökohtansa. Eri instituutioiden tehtävä on \\ luoda oppimiselle suotuisat mahdollisuudet. Sen merkitsee mm. \\ sitä, että koulutusjärjestelmää uudistetaan jatkuvasti soveltumaan \\ aikuiskoulutuksen tarpeisiin. Painopiste tulee siis siirtää \\ koulutusorganisaatioista oppimista tukevien toimintaympäristöjen \\ luomiseen. Tällaisia suuntaviivoja loi seuraajalleen tilaa tehnyt \\ vuosien 1988-90 aikuiskoulutusneuvosto asiakirjassaan \\ Koulutusyhteiskunnasta oppimisen yhteiskuntaan.
}

\section{Jatkuvan oppimisen periaate}

Aikuiskoulutusneuvosto korostaa humanistiseen psykologiaan sekä kognitiiviseen ja toiminnan teoriaan perustuvaa näkemystä ihmisestä aktiivisena tiedonhankkijana ja tiedonkäsittelijänä. Jotta koulutusjärjestelmä tukisi jatkuvaa oppimista, kouluttajien ja ohjaajien koulutus tulee myös järjestyä näiden uusien näkemysten pohjalta.

Aikuiskoulutusneuvosto haluaa nähdä tulevaisuuden koulutusjärjestelmän sellaisena, että siinä nuorten peruskoulutus ja aikuisten monipuoliset opiskelumahdollisuudet ovat tasaveroisessa asemassa.

Eräs keino edistää jatkuvaa koulutusta on kehittää tutkintojen joustava, yhteenniveltyvä jär- jestelmä keinotekoisia raja-aitoja karsien. Uusien asioiden hallinta tulee siis voida osoittaa muunlaisinkin näytöin kuin koulumuotoisella opiskelulla. Kynnystä jatkuvaan koulutukseen voidaan myös madaltaa aikuisten opinto-ohjauksella ja informaatiolla, rohkaisemalla ja kannustamalla aikuista sekä opintotuen ja opintososiaalisten palveluiden joustavilla, aikuisopiskelijaa palvelevilla sovellutuksilla.

\section{Työorganisaatiot ja oppiminen}

Oppimisen yhteiskunnan keskeinen ulottuvuus on työelämä. Pääosa tarvittavasta uudesta osaamisesta on hankittava työssä jo olevaa henkilöstöä kehittämällä, aikuiskoulutusneuvosto toteaa. Jatkuvan oppimisen mahdollisuudet vaikuttavat työntekijäin työkykyyn ja -motivaatioon ja työelämässä pysymiseen. 
Työtä on kehitettävä oppimista edistäväksi ja oppimista kannustavat työyhteisöt voivat merkittävällä tavalla vaikuttaa työntekijöiden elämänhallinnan kehittymiseen laajemminkin.

Keskeisintä on kehittää työtä itseään oppimismahdollisuuksia sisältäväksi. Toinen keskeinen etenemistie on aktiivinen henkilöstökoulutus, luonnollisena osana työtä. Oppimista voidaan myös edistää tukemalla työntekijäin omaehtoista itsensä kehittämistä.

Aikuiskoulutusneuvosto näkee kuitenkin, ettei kaikki tämä onnistu laajassa mitassa ilman erilaisia tukitoimenpiteitä. Vastuu tässä kuuluu niin työmarkkinajärjestöille, oppilaitoksille ja henkilöstöhallinnollekin. Oppilaitosten tulee voimakkaasti kehittää asiakaslähtöistä koulutussuunnitteluaan ja valmiuksiaan. Omaehtoisessa itsensä kehittämisessä on vuorostaan vapaalla sivistystyöllä tärkeä työsarka.

\section{Kansalaiset ja perussivistys}

Neuvosto kantaa myös huolta aikuisten kansalaisen perussivistyksestä, sillä demokratian kannalta se on keskeisiä kysymyksiä. Kansalaisilla tulee olla mahdollisuus hankkia itselleen yhteis- kunnallisesti tärkeitä kysymyksiä monipuolisesti jäsentävää tietoa omien valintojensa ja päätöstensä perustaksi, neuvosto toteaa.

Eräs kansanvallan ominaisuus on se, että kansalaisilla on mahdollisuuksia pohtia niitä arvoja ja eettisiä periaatteita, jotka viime kädessä ohjaavat kaikkea tiedon käyttöä. Kansalaisten tulee kyetä käyttäytymään hankkimansa tiedon perusteella. Tieto on voitava suhteuttaa omaan elämäntapaan, lähi- ja työympäristöön ja laajempiin yhteyksiin niin, että se voi muodostua oman toiminnan ja ratkaisujen pohjaksi.

Erityisen korostuneesti tiedon, arvojen ja toiminnan merkitys tulee vanhan aikuiskoulutusneuvoston mielestä esiin ympäristö- ja energiakysymyksissä.

Pohjatietoa yhteiskunnallisesti tärkeistä kysymyksistä ovat luoneet perinteisesti juuri kansalaisjärjestöt ja näin luoneet mahdollisuuksia arvokysymysten käsittelyyn. Tätä kansalaisjärjestöjen tärkeää työtä tuleekin tukea samalla, kun oppilaitoksilta - mukaan lukien myös ammatilliset oppilaitokset - edellytetään suurempaa vastuuta demokraattisen yhteiskunnan perusedellytyksiä ylläpitävästä ja arvokysymyksiin liittyvästä koulutustarjonnasta. 